Proc. Indian Acad. Sci. (Earth Planet. Sci.), Vol. 92, Number 1, March 1983, pp. 73-80.

C. Printed in India.

\title{
Alkaline basic intrusives of Elchuru, Prakasam District, Andhra Pradesh, India
}

\author{
SATTRAJIT NAG, T E SMITH* and P S CHAKRAVORTY \\ Department of Geological Sciences, Jadavpur University. Calcutta 700 032. India \\ * Department of Geology, University of Windsor, Ontario N9B 3P4. Canada
}

MS received 15 September 1982: revised 13 December 1982

\begin{abstract}
The igneous alkaline rocks at Elchuru start from a parent ijolite-melteigite association to basic malignite, melalusitanite and shonkinite followed by nepheline syenites and then biotite lamprophyres (as dykes) at the waning phase of the evolutionary course of the complex. The distinct alkalinity of the rocks is manifested by the development of modal nepheline and calcic amphibole (kaersutite). For both the basic rocks, i.e. alkali gabbro and biotite lamprophyre, the percentages of normative nepheline are always higher than modal nepheline. indicating silica deficiency and alkali enrichment of the mafics. It is evident from detailed petrological and geochemical studies that the two basic members are very much akin to each other and there is no major deviation in their bulk chemistry.
\end{abstract}

Keywords. Alkaline complex; ijolite-melteigite; malignite; melalusitanite: biotite lamprophyre.

\section{Introduction}

The Elchuru alkaline intrusion $\left(16^{\circ} 05^{\prime} \mathrm{N}: 79^{\circ} 55^{\prime} \mathrm{E}\right)$ is an arcuate ring complex (figure 1) outcropping in the Eastern Ghats high grade metamorphic series (Bose and Nag 1980; Nag et al 1982; Nag and Chakravorty 1983) with abundant development of khondalites, hypersthene bearing granulites and gneisses, anorthosites, granitegneisses, calc-granulites, quart7ites and migmatites (Perraju et al 1979). These rocks have been variously dated by different workers as ranging from $3000-1000 \mathrm{Ma}$ ( $\mathrm{Nag}$ 1983), indicating a complex history for the Eastern Ghats, largely in the Archeans. The close spatial and temporal relationships along with limited radiometric age data on different alkaline plutons of the Eastern Ghats belt, suggest a probable Proterozoic alkaline magmatism (Sarkar 1968: Deans and Powell 1968; Crawford 1969; Subba Rao 1971: Bose 1972: Ray and Bose 1975; Moralev et al 1975), emplaced along deep-seated regional fractures across the high grade host rocks, particularly at Tamil Nadu (Grady 1971; Borodin et al 1971; Srinivasan 1973, 1977; Subramaniam et al 1978). The Elchuru alkaline complex, being a part of Eastern Ghats alkalic episode, is made up of a series of rock types ranging from ijolite-melteigite to alkali gabbro (represented by malignite, melalusitanite and shonkinite) and then to hypersolvus and subsolvus nepheline syenites which are penetrated by late stage biotite lamprophyre dykes. The petrography, mineralogy, geochemistry and modal content of these rocks have been studied to develop a model of the magmatic evolution of the complex. It is pertinent to mention here that the ijolite-melteigite association at Elchuru is a very recent finding (through detailed mapping on $16^{\prime \prime}=1$ mile scale) apart from alkaline gabbros as reported earlier (Madhavan and Leelanandam 1979; Nag 1979; Bose and 


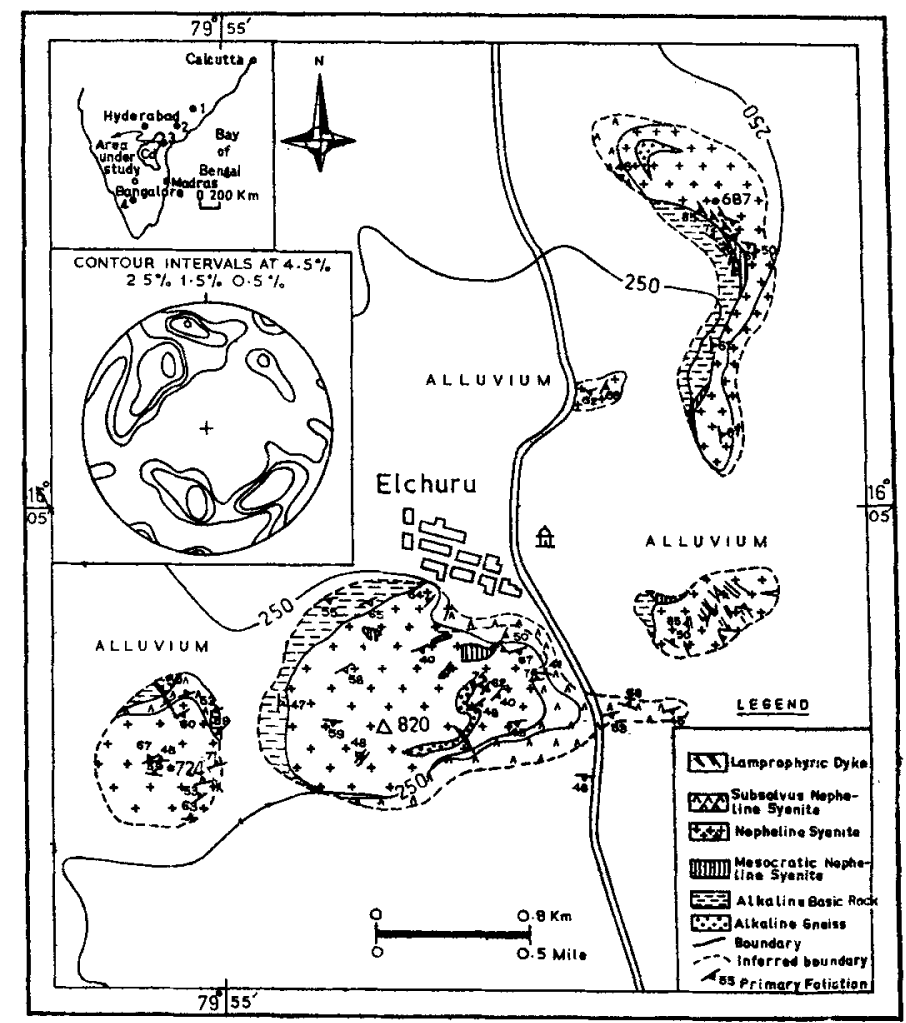

Figure 1. Geological map of Elchuru alkaline complex. Prakasam District, Andhra Pradesh. For inset map: 1. Koraput, Orissa: 2. Kunavaram. Andhra Pradesh; 3. Elchuru, Andhra Pradesh; 4. Sivamalai, Tamil Nadu. Cd-Cuddapah basin.

Nag 1980). An extensive geochemical and petrological account on ijolite-melteigites at Elchuru is discussed elsewhere (Nag 1983).

The purpose of the present paper is to test, using Student's $t$-statistic, whether there is statistically significant difference in modal contents or major and trace element contents and elemental ratios of the early phase alkali gabbros and the biotite lamprophyres. In all instances the null hypothesis was satisfied at the $1 \%$ confidence suggesting that both rock groups were derived from the same population.

\section{Method of study}

Six samples from alkali gabbro and four from biotite lamprophyre were selected for chemical analyses and their modal contents are presented in table 1. Major elements were analysed by rapid method (Shapiro and Brannock 1962) using USGS standards GSP-I and BCR- 1 for countercheck of precision and accuracy of results. Total alkalies were determined by flame photometric technique. The samples were analysed at the Geological Laboratory, Presidency College, Calcutta. Trace elements of both the rock-members were analysed using a Philips PW 1410 Universal vacuum $x$-ray spectrometer at the University of Windsor, Ontario, Canada. Compton scatter peaks were measured for each sample, for USGS standard rock powders W-1, AGV-1, GSP-1 
Table 1. Modal data for alkaline basic rocks of Elchuru. Andhra Pradesh, India

\begin{tabular}{|c|c|c|c|c|c|c|c|c|c|c|}
\hline \multirow[b]{2}{*}{ Serial Numbers } & \multicolumn{6}{|c|}{ Alkali gabbro } & \multicolumn{4}{|c|}{ Biotite lamprophyre } \\
\hline & 1 & 2 & 3 & 4 & 5 & 6 & 7 & 8 & 9 & 10 \\
\hline Clinopyroxene & 12.37 & 32.11 & 5.28 & 26.10 & 13.60 & 3.92 & 14.36 & 27.24 & 38.30 & 41.00 \\
\hline Amphibole & 28.13 & - & 46.37 & 5.72 & 1.24 & 28,12 & 1.23 & - & - & - \\
\hline Biotite & 9.76 & 46.86 & 14.04 & 38.80 & 50.73 & 19.01 & 51.70 & 41.17 & 47.90 & 51.00 \\
\hline Alkali feldspar & 3.1 .81 & 17.44 & 24.76 & 17.43 & 31.25 & 43.80 & 18.50 & 36.52 & 8.50 & 8.00 \\
\hline Nepheline & 14.16 & 2.90 & 8.36 & 6.00 & - & 3.60 & 1.17 & 5.95 & 4.40 & - \\
\hline Apatite & 2.91 & 0.42 & 0.48 & 1.25 & - & 1.07 & 0.22 & 1.05 & - & - \\
\hline Calcite & 0.67 & 0.56 & 0.69 & 0.71 & 3.18 & 0.29 & 0.41 & 0.69 & 0.99 & - \\
\hline Sphene & - & - & - & 3.57 & - & - & - & - & - & - \\
\hline Opaque & 0.19 & - & - & 0.40 & - & 0.19 & 0.63 & 0.26 & - & - \\
\hline Colour index & 53.97 & 79.95 & 66.88 & 76.53 & 68.75 & 52.60 & 68.55 & 70.41 & 87.19 & 92.00 \\
\hline
\end{tabular}

and $\mathrm{G}-2$, and for pure quartz on both $\mathrm{Cr}$ and Mo target tubes. From this data mass absorption values were determined for each sample (Turek et al 1977). The mass absorption values derived from the measurements using Mo tube were used to correct the analyses of $\mathrm{Rb}$ and $\mathrm{Sr}$. The mass absorption values derived from the $\mathrm{Cr}$ tube measurement were used to correct the analysis of $\mathrm{Ba}$.

\section{Discussion}

The basic malignite, melalusitanite and shonkinite are generally made up of coarsegrained subhedral minerals, grading into each other according to variation in mineralogical proportions (Streckeisen 1973). The biotite lamprophyres are fine-grained glomeroporphyritic rocks containing clinopyroxene phenocrysts. The pyroxenes in the alkaline gabbros are ferrosalite $\left(\mathrm{Wo}_{54} \mathrm{Fs}_{26} \mathrm{En}_{20}\right)$ and those in the biotite lamprophyres are salite $\left(\mathrm{Wo}_{45} \mathrm{Fs}_{16} \mathrm{En}_{39}\right)$. Both the basic rocks contain calcic amphibole (kaersutitic; Leake 1978) and Fe-Ti biotites. Microperthitic and cryptoperthitic orthoclase occur in the early basic rocks whereas the feldspar is mesoperthite orthoclase in biotite lamprophyre.

Plots of $\left(\mathrm{Na}_{2} \mathrm{O}+\mathrm{K}_{2} \mathrm{O}\right)-\mathrm{CaO}-\mathrm{MgO}-\left(\mathrm{FeO}+\mathrm{Fe}_{2} \mathrm{O}_{3}\right)$ of alkali gabbros and biotite lamprophyres show no significant chemical differences (figure 2 ) between the two rock types, which also have similar $\mathrm{Fe} / \mathrm{Mg}$ ratio. The ratio $\mathrm{TiO}_{2} \times 100 /\left(\mathrm{FeO}+\mathrm{Fe}_{2} \mathrm{O}_{3}\right)$ when plotted against $\mathrm{TiO}_{2}(w t \%)$ shows that the combined effects of Fe-Ti do not widely differ in early and late stage magmatic events (figure 3). The ratio $\left(\mathrm{Na}_{2} \mathrm{O}+\mathrm{K}_{2} \mathrm{O}\right)$ (molecular proportions) being always less than 1 ranges from 0.83 to 0.93 for basic malignite, melalusitanite and shonkinite and 0.63 to 1.00 for biotite lamprophyres (table 2).

Geochemical studies reveal that the mean $\mathrm{K}, \mathrm{O}, \mathrm{Rb}, \mathrm{Ba}$ contents and $\mathrm{K} / \mathrm{R}$ b ratios of the early basic rocks (5.30\%, $116 \mathrm{ppm}, 2416 \mathrm{ppm}$ and 395.65 respectively) and biotite lamprophyres $(5.13 \%, 135 \mathrm{ppm}, 2322 \mathrm{ppm}$ and 336.13 respectively) are very similar. Average $\mathrm{CaO}$ contents show depletion in lamprophyres $(8.23 \%)$ compared to the gabbroic member $(9.52 \%)$. Strontium shows no significant difference being $1258 \mathrm{ppm}$ and $1204 \mathrm{ppm}$ respectively. The average ratios $\mathrm{Rb} / \mathrm{Sr}$ and $\mathrm{Ba} / \mathrm{Sr}$ are in accordance with their similar magmatic character showing highly significant results at $1 \%$ confi- 


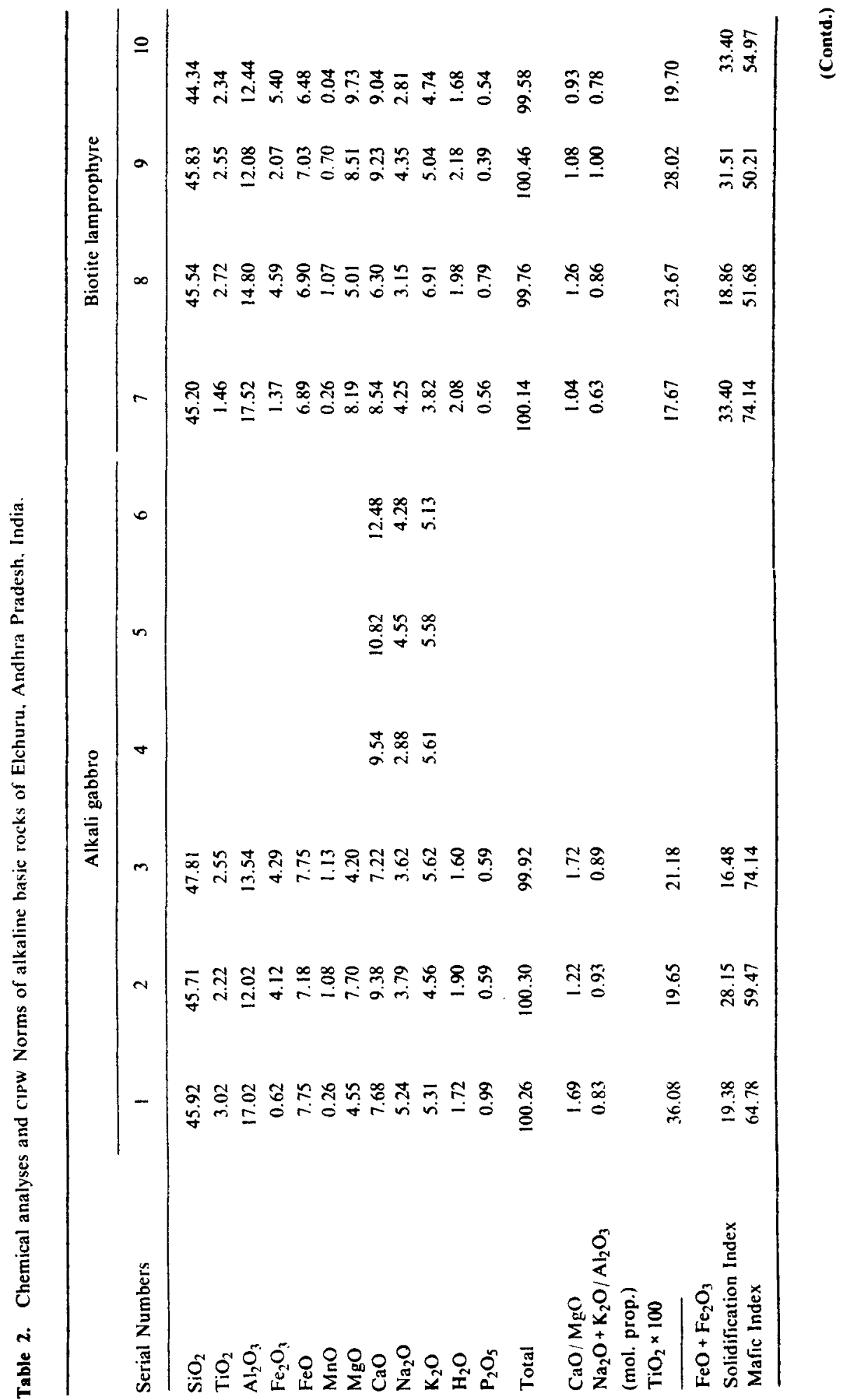




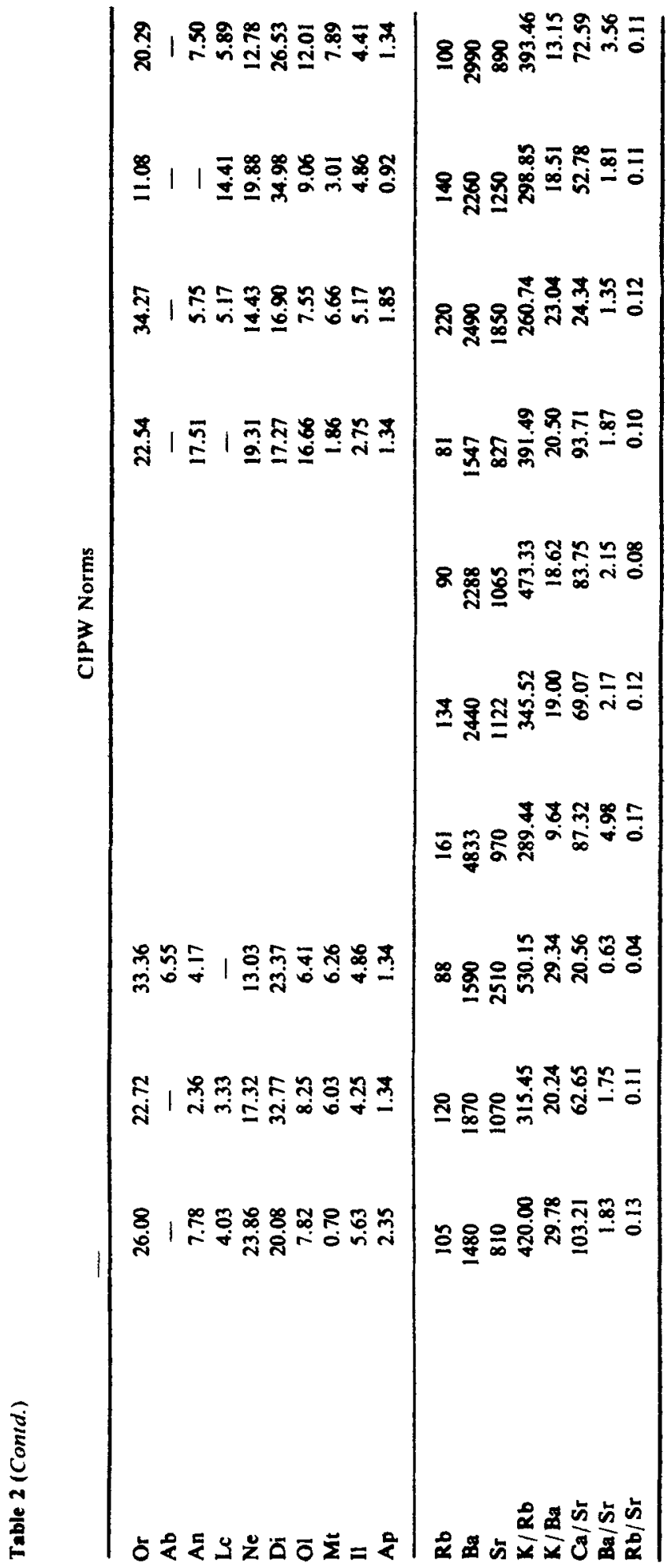




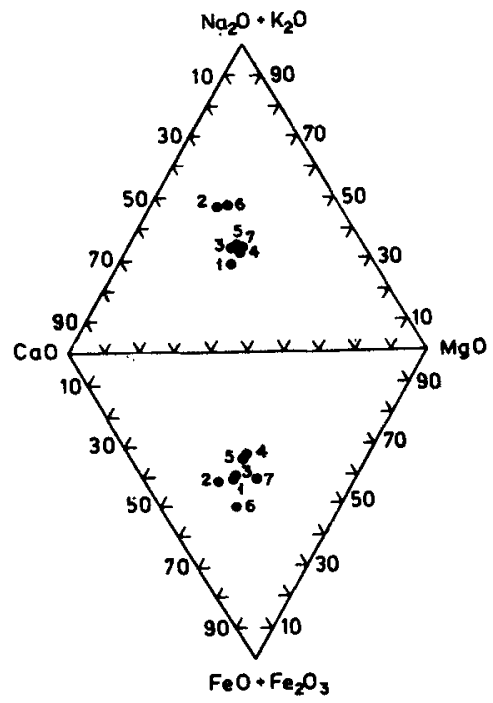

Figure 2. $\left(\mathrm{Na}_{2} \mathrm{O}+\mathrm{K}_{2} \mathrm{O}\right)-\mathrm{CaO}-\mathrm{MgO}-\left(\mathrm{FeO}+\mathrm{Fe}_{2} \mathrm{O}_{3}\right)$ diagram (wt\%) for alkaline basic members of the investigated complex. 1-3. Alkaline gabbro. 4-7. Biotite lamprophyre.

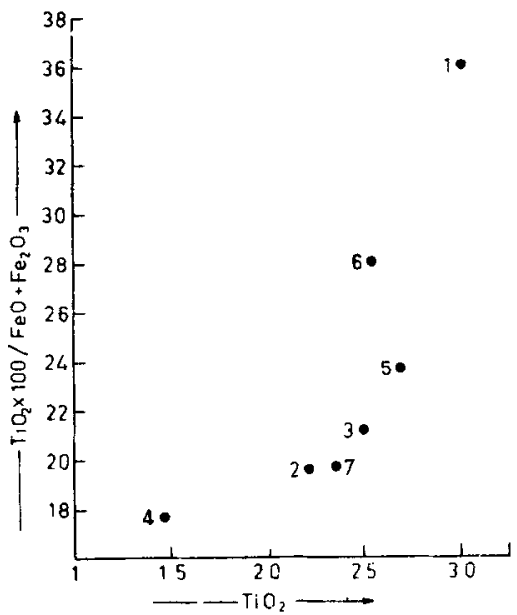

Figure 3. Plots of $\mathrm{TiO}_{2} \times 100 /\left(\mathrm{FeO}+\mathrm{Fe}_{2} \mathrm{O}_{3}\right)(\mathrm{wt} \%)$ as a function of $\mathrm{TiO}_{2}(\mathrm{wt} \%)$ of the alkaline basic members of Elchuru. Explanation same as in Figure 2. 
Table 3. $t$-statistic and test of significance between alkaline basic members of Elchuru, Andhra Pradesh, India.

\begin{tabular}{|c|c|c|c|c|c|c|c|}
\hline Parameters & $\vec{X}_{1}$ & $\sigma_{1}$ & $\overline{X_{2}}$ & $\sigma_{2}$ & $d_{f}$ & $t^{*}$ & $\begin{array}{l}\text { Signi- } \\
\text { ficance }\end{array}$ \\
\hline Alkali feldspar & 27.748 & 9.202 & 17.88 & 11.548 & 8 & 1.340 & $\mathrm{H}_{\mathrm{O}}$ \\
\hline Clinopyroxene & 15.563 & 10.329 & 30.225 & 10.511 & 8 & 1.953 & $\mathrm{H}_{\mathrm{O}}$ \\
\hline Biotite & 29.87 & 16.206 & 47.943 & 4.163 & 8 & 1.952 & $\mathbf{H}_{\mathrm{O}}$ \\
\hline Colour index & 66.447 & 10.303 & 79.538 & 10.221 & 8 & 1.766 & $\mathrm{H}_{\mathrm{O}}$ \\
\hline $\mathrm{SiO}_{2}$ & 46.48 & 9.444 & 45.228 & 5.558 & 5 & 1.851 & $\mathrm{H}_{\mathrm{O}}$ \\
\hline $\mathrm{Ab}_{2} \mathrm{O}_{3}$ & 14.193 & 2.093 & 14.21 & 2.178 & 5 & 0.0086 & $\mathrm{H}_{\mathrm{O}}$ \\
\hline $\mathbf{P}_{2} \mathrm{O}_{3}$ & 7.233 & 1.886 & 0.57 & 0.143 & 5 & 1.034 & $\mathbf{H}_{\mathrm{O}}$ \\
\hline $\mathrm{MgO}$ & 5.483 & 1.574 & 7.86 & 1.743 & 5 & 1.572 & $\mathbf{H}_{\mathrm{O}}$ \\
\hline $\mathrm{CaO}$ & 9.52 & 1.786 & 8.228 & 1.169 & 8 & 1.097 & $H_{O}$ \\
\hline $\mathrm{Na}_{2} \mathrm{O}$ & 4.05 & 0.746 & 3.64 & 0.672 & 8 & 0.811 & $\mathbf{H}_{\mathbf{O}}$ \\
\hline $\mathbf{x}_{2} \mathbf{O}$ & 5.302 & 0.377 & 5.128 & 1.123 & 8 & 0.314 & $\mathbf{H}_{\mathbf{O}}$ \\
\hline $\mathrm{Na}_{2} \mathrm{O}+\mathrm{K}_{2} \mathrm{O}$ & 0.883 & 0.041 & 0.818 & 0.134 & 8 & 0.695 & $\mathbf{H}_{\mathrm{O}}$ \\
\hline $\mathrm{Al}_{2} \mathrm{O}_{3}$ & & & & & & & \\
\hline $\mathrm{CaO} / \mathrm{MgO}$ & 1.543 & 0.229 & 1.078 & 0.119 & 5 & 2.950 & $H_{0}$ \\
\hline$\frac{\mathrm{INO}_{2} \times 100}{\mathrm{FeO}+\mathrm{Fe}_{2} \mathrm{O}_{3}}$ & 25.637 & 7.411 & 22.265 & 3.962 & 5 & 0.645 & $\mathbf{H}_{\mathrm{O}}$ \\
\hline Solidification Index & 21.337 & 4.961 & 29.318 & 6.089 & 5 & 1.568 & $\mathrm{H}_{\mathbf{O}}$ \\
\hline Mafic Index & 66.13 & 6.065 & 57.75 & 9.618 & 5 & 1.119 & $\mathbf{H}_{\mathbf{O}}$ \\
\hline $\mathbf{R b}$ & 116.333 & 25.642 & 135.25 & 53.364 & 8 & 0.669 & $\mathbf{H}_{\mathbf{O}}$ \\
\hline Ba & 2416.833 & 1133.97 & 2321.75 & 519.354 & 8 & 0.140 & $\mathbf{H}_{\mathbf{O}}$ \\
\hline Sr & 1257.833 & 568.95 & 1204.25 & 406.25 & 8 & 0.146 & $\mathrm{H}_{\mathrm{O}}$ \\
\hline $\mathbf{K} / \mathbf{R} \mathbf{b}$ & 395.648 & 86.55 & 336.13 & 57.93 & 8 & 1.079 & $\mathbf{H}_{\mathbf{O}}$ \\
\hline $\mathbf{K} / \mathbf{B a}$ & 21.103 & 6.90 & 18.8 & 3.636 & 8 & 0.548 & $\mathbf{H}_{\mathbf{O}}$ \\
\hline $\mathrm{Ca} / \mathrm{Sr}$ & 71.093 & 26.09 & 60.85 & 25.572 & 8 & 0.548 & $\mathbf{H}_{\mathbf{O}}$ \\
\hline $\mathbf{B a} / \mathbf{S r}$ & 2.252 & 1.324 & 2.148 & 0.840 & 8 & 0.125 & $\mathrm{Ho}_{\mathrm{O}}$ \\
\hline $\mathbf{R b} / \mathbf{S r}$ & 0.108 & 0.041 & 0.11 & 0.007 & 8 & 0.073 & $\mathbf{H}_{\mathbf{O}}$ \\
\hline
\end{tabular}

$* t$ - values at $1 \%$ level of significance where $t 3.365,2.896$ (one sided test) and $4.032,3.355$ (two sided test) at respective degrees of freedom $(d f)=5$ and 8 .

$H_{O}=$ Null hypothesis at $1 \%$ level " that the samples are coming from the same population in 99 cases out of 100 trials" are accepted.

dence level (table 3) and hence, all the geochemical characters suggest a close coherence between the two basic members of Elchuru alkaline complex.

\section{Conclusion}

In summary, the two basic members of Elchuru are very similar in chemistry and mineralogy and it is suggested that the biotite lamprophyres were formed from a basic magma which appeared late in evolutionary sequence of the complex as a result of appreciable hydrous environment by earlier solidification of magmas, metamorphism or rifting (Bailey 1964). Abundance of modal biotite (always $>40 \%$ ) and phenocrysts 
of pyroxene (owing to enhanced growth) in biotite lamprophyre are interpreted as resulting from differences in volatile concentration of the two basic phases.

\section{Acknowledgements}

Sincere thanks to Dr J Huang, Department of Geology, University of Windsor, Ontario, Canada for analysing the trace elements and a few partial analyses of major elements (sl. nos. 4, 5, 6). Dr A Bhattacharyya of RKM Residential College, Narendrapur generously helped the statistical computation work. The work was carried out through the financial assistance of Council of Scientific and Industrial Research, New Delhi.

\section{References}

Bailey D K 1964 J. Geophys. Res. 691103

Borodin L. S. Gopal V. Moralev V M and Subramanian V 1971 J. Geol. Soc. India 12101

Bose M K 1972 24th Int. Geol. Congr. Section 1418

Bose M K and Nag S 1980 Proc. Indian Acad. Sci. (Earth Planet. Sci.) 89383

Crawford A R 1969 J. Geol. Soc. India 10117

Deans T and Powell J L 1968 Nalure (London) 218750

Grady J C $1971 \mathrm{~J}$. Geol. Soc. India 1256

Leake B E 1978 Can. Miner. 16501

Madhavan V and Leelanandam C 1979 N. Jb. Miner. Abh. 136276

Moralev V M. Voronovski S N and Borodin L S 1975 Doklady Akad. Nauk. SSSR 22246

Nag S 1979 Sci. Cult. 45207

Nag S, Chakravorty P S and Smith T E 1982 Proc. 69th Indian Sci. Congr., pt. 111 16 (Abs.)

Nag S and Chakravorty P S 1983 Proc. 70th Indian Sci. Congr. Pt. 1116 (Abs.)

Nag $S 1983$ N. Jb. Miner. Abh. 147 (in press)

Perraju P. Kovach A and Svingor E 1979 J. Geol. Soc. India 20290

Ray S and Bose M K 1975 Chayanica Geol. 11

Sarkar S N 1968 Precambrian stratigraphy and geochronology of Peninsular India (Dhanbad: Dhanbad Publishers) p. 33

Shapiro L and Brannock W W 1962 U.S. Geol. Surv. Bull. 1144-A pp. 56

Srinivasan V $1973 \mathrm{~J}$. Geol. Soc. India 14313

Srinivasan V 1977 J. Geol. Soc. India 18598

Streckeisen A 1973 N. Jb. Miner. Abh. H-4 149

Subba Rao K V 1971 J. Petrol. 12621

Subramaniam V, Viladkar S G and Upendran R 1978 J. Geol. Soc. India 19206

Turek A, Riddle C and Smith T E 1977 Can. J. Spectrosc. 2220 